\title{
Subjective Assessment of Psychological Impact, Awareness, And The Online Learning Experience of Dental Students During The Total Lockdown After The Global COVID-19 Spread: University of Jordan
}

\author{
Salah Al-Omoush \\ University of Jordan
}

Firas Alsoleihat ( $\square$ firas.alsoleihat@ju.edu.jo )

University of Jordan

Rasha A. Alamoush

University of Jordan

Wijdan Elmanaseer

University of Jordan

Ahmad M. Hamdan

University of Jordan

\section{Research Article}

Keywords: coronavirus, dental, COVID-19, disease, pandemic

Posted Date: July 29th, 2021

DOI: https://doi.org/10.21203/rs.3.rs-691958/v1

License: (c) (1) This work is licensed under a Creative Commons Attribution 4.0 International License.

Read Full License 


\section{Abstract}

\section{Background}

The aim of the present study was to assess the psychological impact and awareness of the spread of coronavirus pandemic (COVID-19) in Jordan among dental students at the University of Jordan, as well as assessing student attitudes toward dental learning during the lockdown period imposed by the government.

\section{Methods}

This study was conducted using a questionnaire that was electronically distributed to the largest possible number of Year 3, 4 and 5 dental students. 271 students participated in the survey (Year 3, $n=89$, Year 4, $n=94$, and Year $5, n=88$ ), with a response rate of $40.39 \%$.

\section{Results}

Results indicated considerable psychological impact on dental students during the spread of the COVID19 virus in Jordan, with a high degree of awareness among the students about COVID-19. Furthermore, there was positive feedback about the online learning experience of theoretical subjects but less so for practical and/or clinical subjects with a great deal of reluctance to resume their regular study, especially attendance of dental patient clinics.

\section{Conclusion}

Results of this study highlight the need for launching more awareness programs to reassure the dental students and to restore their confidence in the complete protective ability of the recommended precautions against the contraction of the disease.

\section{Introduction}

Many human diseases with unknown etiology are suggested to be of viral origin with a tendency to cause outbreaks that can become epidemic and pandemic. Hence, it is of paramount importance to conduct continuous research especially for new and novel viruses $[1,2,3]$ especially those that cause persistent threats like AIDS, Avian flu, SARS, MERS, Ebola, and Zika [4].

Coronaviruses (CoV), which belong to a Coronaviridae family, are described as enveloped zoonotic viruses with a large plus-strand RNA genome. These viruses were found in mice, rats, chickens, turkeys, swine, dogs, cats, rabbits, horses, cattle and humans, and they can cause gastroenteritis and respiratory tract diseases $[5,6]$. Many coronaviruses can cause mild respiratory disease in humans, however, SARS$\mathrm{CoV}$ and the Middle East respiratory syndrome coronavirus (MERS-CoV) caused a very severe pneumonia when they spread in 2002 and 2012 respectively [7, 8, 9]. 
In 2019, another novel coronavirus emerged in Wuhan City, China, which also causes pneumonia infection $[10,11]$. In a short time the virus spread to most of the world and on the 30th January 2020, the World Health Organization (WHO) declared a public health emergency because of this novel virus outbreak [12] and on 11th February 2020, WHO named the novel viral pneumonia as "Corona Virus Disease (COVID19)" [13]. COVID19 was announced as a pandemic on 11th March [14]. Globally, as of the 8th of September 2020, there have been 27,236,916 confirmed cases of COVID-19, including 891,031 deaths, reported to WHO [15]. Unlike some viruses such as HBV and human papilloma virus there is yet no efficient vaccines or it may be still under early experimental stages $[16,17]$. Moreover anti-viral agents are deemed helpful only in some viral infections such as HBV and HIV $[18,19]$.

Covid-19 can be transmitted via direct transmission (cough, sneeze, and droplet inhalation transmission) and contact transmission (contact with oral, nasal, and eye mucous membranes) [20,21, 22]. The viral transmission occur not only through the respiratory tract, but also via eye exposure with the virus [23]. Also many studies suggested that COVID-19 can be transmitted through aerosols formed during medical procedures $[23,24,25,26]$. Although the virus has recently emerged many studies have addressed the virus description, transmission and cross-infection precautions.[10,11, 13, 20, 21, 22, 24, 27, 28]. Accordingly, it should be noted that the risk of cross infection in the dental practices and hospitals may be high [27] and that includes both dental practitioners and dental students especially those undergoing clinical training. It has been recommended to suspend all elective dental procedures during the pandemic and only treat dental emergencies while implementing strict cross-infection control measures. These include 1) Taking a very detailed case history with the ability to identify the suspected cases of COVID-19 whom should not be treated and immediately reported, 2) Following all the protocols regarding the recommended personal protective equipment such as eye protection, masks (N95), gloves, face shields and head cover and 3) Infection control during treatment (only emergencies) such as preoperative antimicrobial mouth rinse, using rubber dam isolation, implementing four-handed dentistry, using antiretraction high-speed dental hand pieces, using saliva ejectors with high volume and disinfecting all prosthesis and impressions with disinfectant of at least intermediate level [20, 27, 29, 30, 31].

The virus outbreak is still ongoing rapidly all over the world and consequently all the efforts are directed to reduce and control the infection mainly by quarantine of the infected patients as well as the normal population especially those from the regions having an epidemic outbreak [32]. In fact many countries have adopted quarantine protocols for the majority of their populations to be able to slow down the COVID-19 outbreak and eventually control it. Universities have been affected by lockdown and have had to start using distant learning which may affect students' wellbeing in addition to the COVID-19 impact on them.

The aim of the present study was to assess the psychological impact and awareness of the spread of corona virus pandemic (COVID-19) in Jordan among dental students at the University of Jordan, as well as assessing student attitudes toward dental learning during the lockdown period imposed by the government. 


\section{Methods}

The required ethical approval for conducting this online survey study was obtained from the appropriate ethical committee at the University of Jordan. A questionnaire was electronically sent to Year 3, 4 and 5 dental students (Year 3, $n=270$, Year 4, $n=202$, and Year 5, $n=199$ ), and they were asked to voluntarily participate in electronically answering the survey questions which covers the main research ideas. The survey consisted of 37 questions categorized as follows: three general questions (age, sex, year level), seven questions regarding the psychological impact of COVID-19, twelve questions regarding knowledge and awareness about COVID-19, ten questions about the online learning experience of the students during the COVID-19 curfew period, and five questions about the professional responsibility of the participants as dental students and future dentists regarding the COVID-19 pandemic. The types of the questions used were either Yes/No questions or single best choice questions. SurveyMonkey website was used to create and distribute the survey questions, as well as to collect and analyze the responses of the participants. The survey was open to receive the responses over the period from 11th to 30th of April, 2020. Year 1 and 2 dental students were excluded from the survey, because their curricula do not include preclinical dental lab training or dental clinic training. 271 students participated in the survey (Year 3, $\mathrm{n}=$ 89 , Year $4, n=94$, and Year $5, n=88$ ), with a response rate of $40.4 \%$. The mean age of the participants was 22 years $(S D=0.9)$. 204 of the participants were females $(75.3 \%)$ and 67 were males $(24.7 \%)$. This study is descriptive in nature, and thus all the results of the responses to the questionnaire were presented as percentages.

\section{Results}

Psychological impact of COVID-19

Table A1 shows subjects response to questions related to the psychological impact of the imposed government lockdown which resulted in a switch to online learning. About $85 \%$ of participants were either worried $(63.8 \%)$ or very worried $(21.4 \%)$ about the COVID-19 pandemic, while the rest were not worried about this pandemic. About $73 \%$ were either frustrated (50.7\%) or very frustrated $(21.9 \%)$ about the suspension of their study during the COVID-19 spread in Jordan, while the rest were either not bothered at all $(20.9 \%)$ or even pleased $(6.5 \%)$ about the suspension of study.

About $73 \%$ of the participants did not feel secure when the media in Jordan provided information about the personal details about the COVID-19 infected persons in Jordan. During the COVID-19 curfew period in Jordan, about $40 \%$ of the participants were mainly worried for their life and that of their family, about one third (33.5\%) were mainly worried about their study and graduation, $17.2 \%$ about spreading of the virus, and the rest (10.7\%) about the country. About $78 \%$ of the participants described the psychological impact of COVID-19 spread in Jordan on themselves and their families as moderately serious (41.8\%) or extremely serious (36.5\%), while the rest described it as slightly serious $(14.8 \%)$ or not serious at all (6.9\%). 
Regarding the question "Due to the overall psychological impact of this pandemic, what are you most worried about?", the response of 59.3\% was "About finishing my academic year/graduation", while the response of the remainder (40.7\%) was "About the spread of the virus and the daily increase in the number of newly infected persons". Regarding the question "How do you feel about being in obligatory home quarantine?", the response of around three fourths of the participants $(71.6 \%)$ was "It is the right protective precaution", while the response of $10 \%$ was "Good chance to study and follow up on study material with online learning", the response of $10 \%$ was "Good time for relaxation with my family", and the response of $8.3 \%$ was "Frustrated for being obliged to stay at home".

Knowledge and awareness about the COVID-19 disease

Participants were also asked about their knowledge and awareness of the COVID-19 disease, how the spread of this virus can be minimized, and how this disease can be treated (Table A2). About $94 \%$ of the students have heard about other viral outbreaks such as SARS and Ebola. The vast majority of the students $(97.4 \%)$ rated themselves either sufficiently aware $(58.9 \%)$ or very aware $(38.5 \%)$ about this pandemic. About $68 \%$ of the participants reported that being in the medical field meant that they had the lead in giving advice and instructions to their families, relatives and friends, most of the times $(43.9 \%)$ or always (23.8\%) regarding self-protection from COVID-19 infection, while the rest did so sometimes $(29.1 \%)$ or rarely $(3.2 \%)$.

About $90 \%$ of the students were aware that viruses are dead outside the body while bacteria are alive outside the body. About $75 \%$ of the participants believe that the way viruses spread is different from other microorganisms. $67.8 \%$ of students reported, based on their knowledge, that the main route of spread of COVID-19 virus is via virus-laden droplets that sticks on surfaces during the first 12 hours on metal surfaces and the first 8 hours on cloth fabrics. 31.5\% reported that the air-borne route is the main way of spread while $1.2 \%$ reported infection via oro-fecal route (virus-contaminated food stuff), and none believed it to be transmitted via blood-borne route.

$87.7 \%$ of the respondents indicated, based on their knowledge, that the most likely incubation period of COVID-19 virus before the symptoms appear in the range of 2-14 days, while only $10.5 \%$ indicated it to be about three weeks, $1.85 \%$ reported it to be about one month, and none indicated it to be always less than one week.

About half of the participants (50.3\%) reported that the main practice(s) that mostly increase the possibility of spreading COVID-19 virus are hand shaking, kissing, and hugging habits, and $29.8 \%$ reported it to be being in crowded places without taking the protective measures especially social distancing of at least 2 meters, while only $5 \%$ reported it to be touching elevator buttons and door handles in public places, and $1.9 \%$ indicated it to be using cash instead of electronic payment methods.

About three forth of the participants (72.7\%) believed that the most effective procedure to minimize the spread of COVID-19 virus was staying at home. Other reasons quoted by respondent were, implementation of curfew/public quarantine (12.4\%); using the protective measures as wearing gloves 
and masks, washing hands, etc. (12.5\%); and adhering to social distancing with at least 2 meters away from the nearest person in public places $(7.5 \%)$. About three fourths of participants $(73.9 \%)$ reported that the most effective way to enhance the immune system to protect against COVID 19 was eating healthy food, including fruits that are rich in vitamin C, while $10.6 \%$ reported avoiding stress would help the immune system while $10.6 \%$ reported that exercise was the best way to boost immunity. Taking folk remedies (herbal medicines) such as anise, ginger and garlic and drinking lots of warm water was reported by a minority of respondents as a method of boosting immunity. Finally, and none of the subjected reported that taking antibiotics as prophylaxis would prevent infection with COVID 19.

The majority of the participants (97\%) reported that they either always (75.3\%) or most of the times $(21.6 \%)$ adhere to the recommended protective safety measures like wearing a mask and gloves, as well as washing hands and using antiseptics whenever touching a potentially contaminated surface, while the rest do so sometimes $(1.85 \%)$ or rarely $(1.23 \%)$. Most students were aware that viral infections, as compared to bacterial infections, do not respond to antibiotic treatment $(93.7 \%)$. Similarly, the majority of the students are aware that viral infections can be treated by specifically designed vaccines (93\%). About $80 \%$ of the participants believed that the only effective remedy to cure COVID-19 infection is a specific vaccine yet to be produced; ( $90 \%$ believed that this vaccine would take a relatively long time to be produced). On the other hand, $11.8 \%$ of the participants believed the cure was an antiviral drug yet to be discovered, 8.6\% thought it was an anti-malarial drug (such as hydroxychloroquine) along with antibiotics (such as Azithromycin), and none believed that the cure was a herbal remedy yet to be discovered"

Regarding the sources which the students rely on to get reliable information about the COVID-19, around half of participants (47\%) relied on Jordan National Television, 31.6\% used Facebook and other social media sources, $15 \%$ professional interviews with specialists or experts (local or international) in the relevant field, and the rest (6.5\%) on International TV channels. About half of the participants $(52.1 \%)$ reported that they had read at least one of the recent scientific publications which were sent to them through the Cross Infection Control Committee or the Faculty Council regarding the guidelines and the precautions to be followed when dealing with patients during the COVID-19 pandemic.

Attitudes towards online learning

Table A3 illustrated responses to questions about suspension of regular study and the implementation of online learning as a replacement. $82.3 \%$ of participants expected the period of suspension of regular study to be more than one month, while the rest expected it to be from one week to one month, and none expected it to be just one week. The majority of students described their online learning experience during the curfew period as good (54.4\%), very good (19.5\%) or excellent $(5.1 \%)$, while the rest $(20.93 \%)$ described the online experience as poor. About half of the participants followed all relevent learning material uploaded on the University e-learning platform either most of the time (45.6\%) or always (7.9\%), while the rest did so sometimes (33.95\%) or rarely $(12.6 \%)$.

About $88 \%$ of the students were either satisfied $(66.5 \%)$ or very satisfied $(21.3 \%)$ with the online learning of the theoretical subjects/topics, while the rest (12.2\%) were not satisfied. About $65 \%$ of the participants 
had an online learning experience for practical or clinical courses/topics, $60 \%$ of them were not satisfied with this experience, while the rest were either satisfied (35.7\%) or very satisfied (5.4\%). About $73 \%$ of the participants indicated that suspension of study would not have a great impact on the learning outcomes of the theoretical subjects which were taught online ( $42.8 \%$ minimal negative impact, $19.5 \%$ no impact at all, and $10.7 \%$ minimal positive impact), while the rest either indicated that suspension would have a great negative impact $(16.7 \%)$ or great positive impact $(10.2 \%)$. On the other hand, around half the students (47.1\%) reported that suspension of study would have a great negative impact on the learning outcomes of practical/clinical subjects/topics, while the other half (51.3\%) reported that suspension would not have a significant impact ( $34.4 \%$ minimal negative impact, $11.6 \%$ no impact at all, and $5.3 \%$ minimal positive impact). Furthermore, $60 \%$ of the students noted that suspension would not have a substantial impact on their clinical/practical skills (38.8\% minimal negative impact, $20.7 \%$ no impact at all, and $1.6 \%$ minimal positive impact), while $38.30 \%$ noted that suspension would have a great negative impact.

Students indicated that, the most beneficial methods of online learning were: PowerPoint with voice-over recording uploaded online (34.4\%), online meetings using Zoom (32.1\%), and video presentations uploaded on YouTube (28.8\%). On the other hand, the least beneficial method according to students were: online Microsoft Teams meetings (2.3\%), Facebook (1.4\%), and Moodle ( $0.9 \%)$. Around $80 \%$ of students were either moderately satisfied (50.3\%) or very satisfied (29.6\%) with the contribution of Dental School staff members and University teachers to online learning during the suspension period, while only $18 \%$ were minimally satisfied and $2 \%$ were dissatisfied.

Professional responsibility as dental students towards the COVID 19 pandemic

Table A4 illustrated data related to professional responsibility of dental students toward the COVID 19 pandemic. The majority of the participants $(95.1 \%)$ indicated that they would advise a family member or close relative who exhibited signs and symptoms of COVID 19 to be tested for the virus, while the response of $4.3 \%$ was to hide and isolate them. About $3 / 4$ of the participants $(72.5 \%)$ were willing to volunteer as dentists during the COVID 19 pandemic following a brief training. The vast majority of the participants (92.75\%) were aware that dentists were at the highest risk of exposure to COVID 19 and accept to choose dentistry as a career, while only $5.8 \%$ regretted choosing to study dentistry and $1.45 \%$ were thinking of changing their profession.

Regarding the following question "If a COVID-19 infected person has been completely cured based on the recommended tests, would you still be worried about providing dental treatment to him/her?", around half of respondents $(55.2 \%)$ would still be worried to provide dental treatment to an a patient who was completely cured after being infected with COVID 19 . Around $2 / 3$ of participant $(61.85 \%)$ indicated that they would refuse to come to the University to resume their studies if there were still a few new cases every day and curfew was lifted, while $18.5 \%$ would partially comply to start attending lectures but not pre-clinical laboratories and dental clinics., $12.1 \%$ would partially comply and start attending lectures and 
pre-clinical laboratories but not dental care clinics, while only $7.5 \%$ were prepared to fully comply with theoretical and clinical training.

\section{Discussion}

The results of the present study showed substantial psychological impact on dental students during the spread of COVID-19 virus in Jordan which led to the government decision to impose obligatory home quarantine and the resultant substitution of regular study with online learning. The students were mainly worried about their safety and the safety of their family members as well as the completion of their study. However, most of the students agreed that obligatory home quarantine was the best policy to be imposed. This policy was considered in China, and had been required by the Ministry of Education [33].

This study also showed a high degree of knowledge and awareness about COVID-19 among the dental students in Jordan. Most of the students are well aware about the nature of the virus, how it spreads, what precautions needed to be taken to minimize the spread of the disease, and how the infection can be managed. In addition, most of the students adhered to recommended practices to boost their immune system and to the precautions to protect themselves and the community form the spread of this disease. Students' preferred source of information about COVID 19 was Jordan National Television, followed by social media sources, and professional interviews with specialists or experts (local or international) in the relevant field. Furthermore, half of participants read at least one of the recent scientific publications. In fact, dental students were encouraged to obtain the relevant knowledge from medical journals. Nevertheless language might have been a barrier but there are so many sources that can either be translated or even published by the local authorities including University of Jordan in both Arabic and English. This problem was also encountered by Chinese dental practitioners [34].

This study showed that most the students were positive about online learning of theoretical subjects but not practical and or clinical subjects. As the training of dental students has a substantial practical and clinical components, online learning alone is certainly expected to compromise such training. This is expected to contribute to the worry of the students about being undertrained, and them being less confident about the provision of the appropriate dental care to the patients. Covid- 19 pandemic initiated a total transformation toward online learning especially during quarantine, and thus great improvements in higher education had to take place during a short time [35].

The results demonstrated that most of the students were confused between the desire to resume their regular study and receive the appropriate clinical training and their concern about their own safety and the safety of their family members during this pandemic, similar concern was found in other studies [34, 36]. It appears that most of the students were very scared of the disease so that they could not decide to resume their regular study, especially attendance of dental clinics where they would be expected to provide dental care to the patients. The fear of this novel disease and anxiety levels were the main obstacles in such situations $[34,37,38,39]$. However, most of them realized their professional responsibility toward the fulfillment of this task. Confusion was possibly due to propaganda and hype of 
non-scientific misinformation in the social media which exaggerated the seriousness of the disease and created substantial doubt about the effectiveness of the recommended scientifically-based protective precautions. This highlights the need for launching more awareness programs by dental schools to reassure dental students and to restore their confidence in the complete protective ability of the recommended precautions against the contraction of the disease. This is in line with other studies [34, 36, 40]. In the present study, most of the participants stated that they would adhere to PPE protocols. Adherence to PPE protocols and routines is crucial for protection [20], for instance some simple measures such as hand hygiene can be a crucial factor in infection control, nonetheless it is believed adherence to such measures is limited $[20,41]$.

\section{Limitations}

This study mainly acquired information through a questionnaire-based survey, which was found to be effective and informative [42]. However, limitations to this study might be the low response rate which might be attributed to the fact that most students were more dedicated to their online learning, nevertheless the sample size is reflective.

\section{Conclusion}

This study can help policy makers along with dental teaching institutions improve knowledge, to provide psychological support, practical protocols of safety and self and other protection in viral outbreaks.

The results of this study highlight the need for launching more awareness programs conducted by dental schools to reassure dental students and to restore their confidence in the complete protective ability of the recommended precautions against the contraction of the disease.

\section{Abbreviations}

COVID-19: Coronavirus disease of 2019

AIDS: Acquired immunodeficiency syndrome

SARS: Severe acute respiratory syndrome

MERS: Middle East respiratory syndrome

CoV: Coronavirus

RNA: Ribonucleic acid

WHO: World Health Organization

HBV: Human papilloma virus 
HIV: Human immunodeficiency virus

SD: Standard deviation

PPE: Personal protective equipment

\section{Declarations}

All authors declare no conflict of interest, and that this study did not receive any financial support.

\section{Ethics approval and consent to participate}

Informed consent was obtained from all participants. Participation was voluntary and anonymous. The questionnaire included information for consent before participation.

This study was approved by the Ethical Committee of the Deanship of Scientific Research at the University of Jordan (\#2020-117).

All methods were carried out in accordance with relevant guidelines and regulations, notably the Declaration of Helsinki.

\section{Consent for publication}

Not applicable (no individual person's data).

\section{Availability of Data and Materials}

The datasets used and/or analyzed during the current study are available from the corresponding author on reasonable request.

\section{Competing interests}

The authors declare that they have no competing interests.

\section{Funding}

This project did not receive any funding.

\section{Authors' Contributions}

All authors conceived the study idea, performed the literature review, and developed the survey design and questionnaire. All authors provided their feedback on items, questionnaires, data analysis and discussion. All authors participated in the revision of the manuscript. The authors read and approved the final manuscript.

\section{Acknowledgments}


To all the students of the dental school of the University of Jordan who participated in the survey of the present study for answering the questions of the survey. This study was conducted at the University of Jordan.

\section{References}

1. Stohlman SA, Hinton DR. Viral induced demyelination. Brain Pathol. 2001;11:92.

2. Jubelt B, Berger JR. Does viral disease underlie ALS? Lessons from the AIDS pandemic. Neurology. 2001;57:945.

3. Shingadia D, Bose A, Booy R. Could a herpesvirus be the cause of Kawasaki disease? Lancet Infect Dis. 2002;2:310.

4. Reperant LA, Osterhaus ADME. AIDS, Avian flu, SARS, MERS, Ebola, Zika... what next? Vaccine. 2017;35:4470.

5. Holmes KV, Lai MMC. Coronaviridae. In: Fields BN et al. Fields Virology. Philadelphia: Lippincott-Raven Publishers, 1996.

6. Guy JS, Breslin JJ, Breuhaus B, Vivrette S, Smith LG. Characterization of a coronavirus isolated from a diarrheic foal. J Clin Microbiol. 2000;38:4523.

7. Holmes KV. SARS-associated coronavirus. N Engl J Med. 2003;348:1948.

8. The Lancet. MERS-CoV: a global challenge. Lancet. 2013;381:1960.

9. Falsey AR, Walsh EE. Novel coronavirus and severe acute respiratory syndrome. Lancet. 2003;361:1312.

10. Zhu N, Zhang D, Wang W, et al. A novel coronavirus from patients with pneumonia in China, 2019. N Engl J Med. 2020;382:727.

11. Wang C, Horby PW, Hayden FG, Gao GF. A novel coronavirus outbreak of global health concern. Lancet. 2020;395:470.

12. Mahase E. China coronavirus: WHO declares international emergency as death toll exceeds 200 . Br Med J. 2020;368:m408.

13. Gorbalenya AE, Baker SC, Baric RS, et al. The species Severe acute respiratory syndrome-related coronavirus: classifying 2019-nCoV and naming it SARS-CoV-2. Nat Microbiol. 2020;5:536.

14. World Health Organization (WHOa). WHO Director-General's opening remarks at the media briefing on COVID-19 - 11 March 2020, 2020. Retrieved from https://www.who.int/dg/speeches/detail/who-directorgeneral-s-opening-remarks-at-the-media-briefing-on-covid-19-11-march-2020. 
15. World Health Organization (WHOb), 2020. Retrieved from

https://www.who.int/emergencies/diseases/novel-coronavirus-2019/situation-reports.

16. To KK, Hung IF, Chan JF, Yuen KY. From SARS coronavirus to novel animal and human coronaviruses. J Thorac Dis. 2013;5 Suppl 2:S103.

17. Liu C, Zhou Q, Li Y, et al. Research and Development on Therapeutic Agents and Vaccines for COVID19 and Related Human Coronavirus Diseases. ACS Cent Sc. 2020;6:315.

18. De Clercq E. Antivirals and antiviral strategies. Nat Rev Microbiol. 2004;2:704.

19. Lou Z, Sun Y, Rao Z. Current progress in antiviral strategies. Trends Pharmacol Sci. 2014;35:86.

20. Peng X, Xu X, Li Y, Cheng L, Zhou X, Ren B. Transmission routes of 2019-nCoV and controls in dental practice. Int J Oral Sci. 2020;12:9.

21. Lu CW, Liu XF, Jia ZF. 2019-nCoV transmission through the ocular surface must not be ignored. Lancet. 2020;395:e39.

22. World Health Organization (WHOc). WHO/2019-nCoV/Sci_Brief/Transmission_modes/2020.2, 2020. Retrieved from https://www.who.int/publications-detail/modes-of-transmission-of-virus-causing-covid-19implications-for-ipc-precaution-recommendations.

23. To KK, Tsang OT, Yip CC, et al. Consistent Detection of 2019 Novel Coronavirus in Saliva. Clin Infect Dis. 2020;71:841.

24. Wax RS, Christian MD. Practical recommendations for critical care and anesthesiology teams caring for novel coronavirus (2019-nCoV) patients. Can J Anesth/J Can Anesth. 2020;67:568.

25. van Doremalen N, Bushmaker T, Morris DH, et al. Aerosol and Surface Stability of SARS-CoV-2 as Compared with SARS-CoV-1. N Engl J Med. 2020;382:1564.

26. Ong SWX, Tan YK, Chia PY, et al. Air, Surface Environmental, and Personal Protective Equipment Contamination by Severe Acute Respiratory Syndrome Coronavirus 2 (SARS-CoV-2) From a Symptomatic Patient. JAMA. 2020;323:1610.

27. Meng L, Hua F, Bian Z. Coronavirus Disease 2019 (COVID-19): Emerging and Future Challenges for Dental and Oral Medicine. J Dent Res. 2020;99:481.

28. Liu J, Liao X, Qian S, et al. Community Transmission of Severe Acute Respiratory Syndrome Coronavirus 2, Shenzhen, China, 2020. Emerg Infect Dis. 2020;26:1320.

29. Ge ZY, Yang LM, Xia JJ, Fu XH, Zhang YZ. Possible aerosol transmission of COVID-19 and special precautions in dentistry. J Zhejiang Univ Sci B. 2020;21:361. 
30. Samaranayake LP, Reid J, Evans D. The efficacy of rubber dam isolation in reducing atmospheric bacterial contamination. ASDC J Dent Child. 1989;56:442.

31. Hu T, Li G, Zuo Y, Zhou X. Risk of hepatitis B virus transmission via dental handpieces and evaluation of an anti-suction device for prevention of transmission. Infect Control Hosp Epidemiol. 2007;28:80.

32. World Health Organization (WHOb). Coronavirus disease 2019 (COVID-19): situation report-70 [accessed 2020 Marc 31], 2020. Retrieved from https://www.who.int/docs/defaultsource/coronaviruse/situation-reports/20200330-sitrep-70-covid-19.pdf?sfvrsn=7e0fe3f8_2.

33. Meng L, Hua F, Bian Z. Response to the Letter to the Editor: How to Deal with Suspended Oral Treatment during the COVID-19 Epidemic. J Dent Res. 2020;99:988.

34. Hua F, Qin D, Yan J, Zhao T, He H. COVID-19 Related Experience, Knowledge, Attitude, and Behaviors Among 2,669 Orthodontists, Orthodontic Residents, and Nurses in China: A Cross-Sectional Survey. Front Med (Lausanne). 2020;7:481.

35. Strielkowski, W. COVID-19 Pandemic and the Digital Revolution in Academia and Higher Education. Preprints 2020, 2020040290 (doi: 10.20944/preprints202004.0290.v1).

36. Ahmed MA, Jouhar R, Ahmed N, et al. Fear and Practice Modifications among Dentists to Combat Novel Coronavirus Disease (COVID-19) Outbreak. Int J Environ Res Public Health. 2020;17:2821.

37. Sun N, Wei L, Shi S, et al. A qualitative study on the psychological experience of caregivers of COVID19 patients. Am J Infect Control. 2020;48:592.

38. Bansal P, Bingemann TA, Greenhawt M, et al. Clinician Wellness During the COVID-19 Pandemic: Extraordinary Times and Unusual Challenges for the Allergist/Immunologist. J Allergy Clin Immunol Pract. 2020;8:1781.e3.

39. Ng K, Poon BH, Kiat Puar TH, et al. COVID-19 and the Risk to Health Care Workers: A Case Report. Ann Intern Med. 2020;172:766.

40. Kumar S, Tadakamadla J, Areeshi AYBH, Tobaigy HAWM. Knowledge and attitudes towards HIV/AIDS among dental students of Jazan University, Kingdom Saudi Arabia. Saudi Dent J. 2018;30:47.

41. Boyce JM, Pittet D. Healthcare Infection Control Practices Advisory Committee; HICPAC/SHEA/APIC/IDSA Hand Hygiene Task Force. Guideline for Hand Hygiene in Health-Care Settings. Recommendations of the Healthcare Infection Control Practices Advisory Committee and the HICPAC/SHEA/APIC/IDSA Hand Hygiene Task Force. Society for Healthcare Epidemiology of America/Association for Professionals in Infection Control/Infectious Diseases Society of America. MMWR Recomm Rep. 2002;51(RR-16):1, quiz CE1. 
42. Kelley K, Clark B, Brown V, Sitzia J. Good practice in the conduct and reporting of survey research. Int J Qual Health Care. 2003;15:261.

\section{Tables}

Table A1: The psychological impact of COVID-19 


\begin{tabular}{|c|c|}
\hline Psychological impact of & Response \\
\hline \multirow[t]{3}{*}{ COVID-19 Pandemic } & Very worried $(21.4 \%)$ \\
\hline & Worried $(63.8 \%)$ or \\
\hline & Not worried \\
\hline \multirow{4}{*}{$\begin{array}{l}\text { The suspension of their study during } \\
\text { the COVID-19 spread in Jordan }\end{array}$} & Very frustrated $(21.9 \%)$ \\
\hline & Frustrated $(50.7 \%)$ \\
\hline & Not bothered at all (20.9\%) \\
\hline & Pleased (6.5\%) \\
\hline \multirow{2}{*}{$\begin{array}{l}\text { Media revealing personal information } \\
\text { of COVID-19 infected cases. }\end{array}$} & Feeling insecure (73\%) \\
\hline & Feeling Secure (27\%) \\
\hline \multirow{4}{*}{$\begin{array}{l}\text { Worrying about their life and that of } \\
\text { their family }\end{array}$} & Worried about their life and their family ( $40 \%)$ \\
\hline & Worried about their study and graduation (33.5\%) \\
\hline & Spreading of the virus $(17.2 \%)$ \\
\hline & About the country $(10.7 \%)$ \\
\hline \multirow{4}{*}{$\begin{array}{l}\text { Psychological impact of COVID-19 on } \\
\text { themselves and their families }\end{array}$} & Extremely serious (36.5\%) \\
\hline & Moderately serious (41.8\%) \\
\hline & Slightly serious (14.8\%) \\
\hline & Not serious at all (6.9\%). \\
\hline \multirow[t]{3}{*}{ What are you most worried about?" } & "About finishing my academic year/graduation" \\
\hline & $(59.3 \%)$ \\
\hline & $\begin{array}{l}\text { "About the spread of the virus and the daily increase in the } \\
\text { number of newly infected persons" }(40.7 \%)\end{array}$ \\
\hline \multirow{4}{*}{$\begin{array}{l}\text { "How do you feel about being in } \\
\text { obligatory home quarantine?" }\end{array}$} & "It is the right protective precaution" (71.6\%) \\
\hline & $\begin{array}{l}\text { "Good chance to study and follow up on study material } \\
\text { with online learning" (10\%) }\end{array}$ \\
\hline & "Good time for relaxation with my family" (10\%) \\
\hline & "Frustrated for being obliged to stay at home" (8.3\%) \\
\hline
\end{tabular}

\section{Table A2: Knowledge and awareness about the COVID-19 disease}




\begin{tabular}{|c|c|}
\hline Knowledge and awareness about & Response \\
\hline Viral outbreaks & $\begin{array}{l}\text { About } 94 \% \text { of the students have heard about other } \\
\text { viral outbreaks such as SARS and Ebola. }\end{array}$ \\
\hline \multirow[t]{2}{*}{ COVID-19 pandemic. } & Sufficiently aware (58.9\%) \\
\hline & Very aware (38.5\%) \\
\hline \multirow{4}{*}{$\begin{array}{l}\text { Giving advice and instructions to their } \\
\text { families, relatives, and friends regarding self- } \\
\text { protection from COVID- } 19 \text { infection being } \\
\text { from the medical field }\end{array}$} & Most of the times (43.9\%) \\
\hline & Always (23.8\%) \\
\hline & Sometimes (29.1\%) \\
\hline & Rarely (3.2\%). \\
\hline \multirow[t]{4}{*}{ The main route of spread of COVID-19 } & $\begin{array}{l}\text { Virus-laden droplets that sticks on surfaces during } \\
\text { the first } 12 \text { hours }(67.8 \%)\end{array}$ \\
\hline & Air-borne route (31.5\%) \\
\hline & Feco-oral route $(1.2 \%)$ \\
\hline & Blood-borne route (None) \\
\hline \multirow[t]{4}{*}{ Incubation period of } & $2-14$ days $(87.7 \%)$ \\
\hline & Three weeks (10.5\%) \\
\hline & About one month $(1.9 \%)$ \\
\hline & Always less than one week (None) \\
\hline \multirow{4}{*}{$\begin{array}{l}\text { The most effective procedure(s) to minimize } \\
\text { the spread of COVID-19 virus }\end{array}$} & Staying at home $(72.7 \%)$ \\
\hline & Curfew/public quarantine (12.4\%) \\
\hline & Using the protective measures $(7.5 \%)$ \\
\hline & Social distancing $(7.5 \%)$ \\
\hline \multirow{6}{*}{$\begin{array}{l}\text { The most effective way to enhance the } \\
\text { immune system for having less chance of } \\
\text { being infected with COVID-19 virus }\end{array}$} & Eating healthy food (73.9\%) \\
\hline & Avoiding stress (10.6) \\
\hline & Doing some exercise (10.6\%) \\
\hline & Taking folk remedies (herbal medicines) $(2.5 \%)$ \\
\hline & Drinking lots of warm water (2.5\%) \\
\hline & Taking antibiotics as prophylaxis (None) \\
\hline \multirow{3}{*}{$\begin{array}{l}\text { Adherence to the recommended protective } \\
\text { safety measures }\end{array}$} & Always (75.3\%) \\
\hline & Most of the times $(21.6 \%)$ \\
\hline & Sometimes (1.9\%) \\
\hline
\end{tabular}


Rarely (1.2\%).

Viral infections treatment

Aware that viral infections can be treated by specifically designed vaccines (93\%)

Not aware of that $(7 \%)$

Effective remedy to cure COVID-19 infection

A specific vaccine yet to be produced (79.6\%) (90\%) of those believed that this vaccine takes a relatively long time (about one year) to be produced, and the remainder of those (9.9\%) believed it only takes a short period of time (less than four months) for this vaccine to be produced).

An antiviral drug yet to be discovered (11.8\%)

An anti-malarial drug (such as hydroxychloroquine) along with antibiotics (such as Azithromycin) $(8.6 \%)$

A herbal remedy yet to be discovered (none)

The source on which the students rely to get reliable information about the COVID-19,
The Jordan National Television (47\%)

Facebook and other social media sources (31.6\%)

Professional interviews with specialists or experts (local or international) in the relevant field (15\%) International TV channels (6.5\%)

Read at least one of the recent scientific publications (sent to them through the Cross Infection Control Committee or the Faculty Council regarding the guidelines and the precautions to be followed when dealing with patients during the COVID-19 pandemic)
Read (52.1\%)

Did not read any (47.9\%)

\section{Table A3: The online learning}




\section{The online learning}

The period of suspension of regular study

Online learning experience

Following all the relevant material that are uploaded on the formal e-learning platform regarding their courses of study

Online learning of the theoretical subjects/topics

Online learning experience for practical or clinical courses/topi
Impact on the learning outcomes of the theoretical subjects

Suspension of study impact on the learning outcomes of the practical/clinical subjects/topics

\section{Response}

More than one month (82.3\%)

One week to one month

$(17.7 \%)$

Just one week (None)

Excellent (5.1\%)

Very good (19.5\%)

Good (54.4\%)

Bad $(20.9 \%)$

Most of the time (45.6\%)

Always (7.9\%)

Do so sometimes (34\%)

Rarely (12.6\%).

Very satisfied (21.3\%)

Satisfied (66.5\%)

(12.2\%) were not satisfied

Very satisfied (5.4\%).

Satisfied (35.7\%)

Not satisfied (60\%)

Great positive impact (10.2\%)

Minimal positive impact $(10.7 \%)$

No impact at all (19.5\%)

Minimal negative impact $(42.8 \%)$

Great negative impact $(16.7 \%)$

Great positive impact (1.6\%)

Minimal positive impact (5.3\%)

No impact at all (11.6\%)

Minimal negative impact $(34.4 \%)$ 


\begin{tabular}{|c|c|}
\hline & Great negative impact (47\%) \\
\hline \multirow[t]{5}{*}{ Impact on their clinical/practical skills } & Great positive impact $(0.5 \%)$ \\
\hline & $\begin{array}{l}\text { Minimal positive impact } \\
(1.6 \%)\end{array}$ \\
\hline & No impact at all $(20.7 \%)$ \\
\hline & $\begin{array}{l}\text { Minimal negative impact } \\
(38.8 \%)\end{array}$ \\
\hline & Great negative impact (38.3\%) \\
\hline \multirow[t]{5}{*}{ The most beneficial methods of online learning are the followings } & $\begin{array}{l}\text { PowerPoint with voice-over } \\
\text { recording uploaded online } \\
(34.4 \%)\end{array}$ \\
\hline & $\begin{array}{l}\text { Online meetings using Zoom } \\
(32.0 \%) \text {, }\end{array}$ \\
\hline & $\begin{array}{l}\text { Video presentations on } \\
\text { YouTube }(28.9 \%)\end{array}$ \\
\hline & $\begin{array}{l}\text { Online Microsoft Teams } \\
\text { meetings }(2.3 \%) \text {, }\end{array}$ \\
\hline & $\begin{array}{l}\text { Facebook (1.4\%) and Moodle } \\
(0.9 \%) \text {. }\end{array}$ \\
\hline \multirow{4}{*}{$\begin{array}{l}\text { The contribution of the dental school staff members and university } \\
\text { teachers regarding the online learning during the suspension period }\end{array}$} & Very satisfied (29.6\%) \\
\hline & Moderately satisfied (50.3\%) \\
\hline & Minimally satisfied (18\%) \\
\hline & Dissatisfied (2\%) \\
\hline
\end{tabular}

Table A4: Professional responsibility of dental students towards the COVID 19 pandemic 


\section{Question}

"If one of your family members or a close relative shows some of the COVID-19 infection symptoms; such as, constant fever, dry cough and breathing difficulty, what will you do?"

\section{Response}

(95.1\%) to advise him/her to do the COVID-19 virus test

(4.3\%) to hide and isolate him/her

$(0.6 \%)$ to deal with him/her as a person with simple flu

None to advise him/her to take herbal remedies and simple medications.

(72.5\%) "yes"

(27.5\%) "no".

$(92.75 \%)$ was "I was aware of such circumstances and accepted to choose dentistry"

(5.8\%) was "I will regret choosing to study dentistry"

(1.45\%) was "I am thinking of changing my profession".

(55.2\%) was "yes"

(44.8\%) was "no".

(61.9\%) was "Will refuse to come to university", (18.5\%) was "Will partially comply with the announcement and start attending lectures but not pre-clinical laboratories and dental clinics"

$(12.1 \%)$ was "Will partially comply with the announcement and start attending lectures and pre-clinical laboratories but not dental care clinics"

(7.5\%) was "Will totally comply with the announcement and start attending lectures, preclinical laboratories, and dental care clinics, as well as providing dental care to the patients". 